\title{
Homelessness and the 'over-judicialisation' of welfare
}

\author{
Emma Laurie Li $^{\dagger \dagger}$ \\ Law School, University of Southampton, Southampton, UK \\ *Author email: emma.laurie@soton.ac.uk
}

(Accepted 20 May 2020)

\begin{abstract}
Members of the senior judiciary have expressed concern about the 'over-judicialisation' of welfare in the context of homelessness decision-making and adjudication. This paper examines how those fears have been manifested and makes a link with the concept of proportionate dispute resolution (PDR). It argues that the statutory scheme incorporates elements of PDR and judges should therefore refrain from introducing additional layers. The courts' denial of the application of Article 6 of the European Convention on Human Rights to the homelessness context is disputed, and the paper makes the case for continuing rigorous judicial oversight of front-line decision-making, recommending that attention is focused on assessing procedural safeguards rather than disputing the ambit of Article 6.
\end{abstract}

Keywords: administrative decision-making; proportionate dispute resolution; homelessness; Article 6 ECHR; overjudicialisation

\section{Introduction}

Record levels of homeless households and unprecedented numbers of rough sleepers have created renewed focus on the assistance provided by English local housing authorities, and additional duties have recently been imposed on them. ${ }^{1}$ Even before these changes, the English homelessness scheme has been lauded as one of the most progressive in the world, ${ }^{2}$ providing a relatively generous definition of homelessness ${ }^{3}$ and an individually enforceable right to state assistance, provided certain criteria are met. Nevertheless, since its inception, the statutory scheme has represented a compromise between granting individual rights and giving the local housing authorities who administer the scheme flexibility to consider local conditions. This paper argues that the courts have been generally reluctant to grant homelessness adjudication the status it deserves by consistently emphasising the discretionary character of the homelessness duties and thus the administrative nature of the decision-making. In this vein, the Supreme Court has warned against 'over-judicialisation' in order to avoid wasting public money on unnecessary adjudication. ${ }^{4}$ The central contention of this paper is that the statutory scheme already incorporates requirements to ensure 'proportionate dispute resolution' (PDR), and accordingly it is inappropriate for the courts to introduce informally further measures for cost-saving reasons. The courts' actions risk denying justice to a group of people acknowledged to be among the most

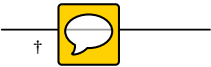

${ }^{1}$ Homelessness Reduction Act 2017.

${ }^{2}$ S Fitzpatrick and N Pleace 'The statutory homelessness system in England: a fair and effective rights-based model?' (2012)

27 Housing Studies 232 at 233.

${ }^{3}$ Housing Act 1996, s 175 .

${ }^{4}$ Runa Begum v Tower Hamlets London Borough Council [2003] UKHL 5 at [5] per Lord Bingham. 
vulnerable in society, ${ }^{5}$ with one author suggesting that 'a significantly diluted version of the rule of law ...' is being applied. ${ }^{6}$

The Supreme Court's warning against over-judicialisation has manifested itself in two distinct but related ways. First, it has instructed the lower courts to take a 'benevolent approach" ${ }^{77}$ to housing officers' decisions when reviewing their legality. Secondly, the court has denied the applicability of Article 6 of the European Convention on Human Rights (ECHR) to the homelessness review process. The desire to conserve judicial resources extends beyond the homelessness context and the arguments presented here have wider relevance to the relationship between administrative justice and human rights. Parallels will be drawn with other areas of administrative decision-making where resource concerns have predominated over those of individual justice.

This paper questions the judiciary's use of the term over-judicialisation and locates it within the framework of PDR - a concept which came to prominence in the 2000s as the central plank of the then government's administrative justice agenda ${ }^{8}$ and which remains a core principle. ${ }^{9}$ PDR captures the idea 'that the ways in which cases are dealt with should reflect the nature of the dispute and what the person in dispute with a government department or public body wishes to achieve.. ${ }^{10}$ More controversially, PDR is associated with reducing judicial involvement in administrative adjudication. ${ }^{11}$ Striking the balance between judicial intervention and agency autonomy is an enduring dilemma of administrative law, ${ }^{12}$ and there is a substantial body of literature analysing the courts' role in adjudicating cases involving issues of resource allocation. ${ }^{13}$ While the courts are right to respect the leeway given to local authorities by the statutory framework, it is inappropriate for them to dilute the standard of review by instructing a benevolent approach to interpreting internal review decisions.

The first section of this paper outlines the legislative provisions to explain their hybrid character and local authorities' scope for discretion. The second section examines the concept of PDR and locates homelessness decision-making and adjudication within its framework. The origin of the benevolent approach is then explored, followed by the body of research which evidences the poor quality of homelessness decision-making. The paper then proceeds to analyse a series of cases in which the Supreme Court has not followed its own instruction, by explicitly or implicitly requiring more forensic scrutiny of front-line decisions, to discern whether there is a unifying principle to guide both decisionmakers and the lower courts. The final section analyses the disagreement between the European Court of Human Rights (ECtHR) and the domestic courts (and government) regarding the applicability of Article 6 and what it reveals about their attitudes towards judicial oversight of administrative decisionmaking and, specifically, whether those decisions are worthy of the protection of human rights standards.

\footnotetext{
${ }^{5}$ Public Health England Guidance Homelessness: Applying All Our Health, 2 November 2018.

${ }^{6}$ I Loveland 'Reforming the homelessness legislation? Exploring the constitutional and administrative legitimacy of judicial law-making' (2018) PL 299 at 306.

${ }^{7}$ Holmes-Moorhouse v Richmond-upon-Thames London Borough Council [2009] UKHL 7 at [50] per Lord Neuberger.

${ }^{8}$ Department for Constitutional Affairs Transforming Public Services: Complaints, Redress and Tribunals Cm 6243 (July 2004) para 2.2.

${ }^{9}$ Ministry of Justice Administrative Justice and Tribunals: Final Report of Progress against the Strategic Work Programme 2013-2016, Cm 9319 (March 2017) p 3.

${ }^{10} \mathrm{M}$ Adler 'Tribunal reform: proportionate dispute resolution and the pursuit of administrative justice' (2006) 69(6) MLR 258 at 259.

${ }^{11}$ House of Commons Public Administration Select Committee Oversight of Administrative Justice Written Evidence Evidence submitted by the Administrative Justice and Tribunals Council, p 20.

${ }^{12} \mathrm{M}$ Elliott and R Thomas 'Tribunal justice and proportionate dispute resolution' (2012) CLJ 297 at 298. More broadly see Lord Sumption 'The limits of law' the 27th Sultan Azlan Shah Lecture, Kuala Lumpur, 20 November 2013, available at https:// www.supremecourt.uk/docs/speech-131120.pdf (accessed 26 May 2020).

${ }^{13}$ See eg E Palmer Judicial Review, Socio-Economic Rights and the Human Rights Act (Oxford: Hart Publishing, 2007); D Wang 'Social rights adjudication and the nirvana fallacy' (2018) PL 482; J King 'The justiciability of resource allocation' (2007) 70(2) MLR 197; RA Edwards 'Judicial deference under the Human Rights Act' (2002) 65 MLR 859.
} 


\section{The Janus-faced homelessness scheme}

The homelessness scheme was controversial from its inception in $1977,{ }^{14}$ by replacing an exhortatory government circular $^{15}$ with statutory duties. The Bill was strongly opposed by some MPs and the final Act was a product of compromise, ${ }^{16}$ with significant discretion granted to local authorities in determining the scope of the key qualifying criteria. Nevertheless, at the core of the Act is an individually legally enforceable right for applicants who fulfil those criteria, and this position has been maintained despite numerous changes to the legislative framework. Writing in 1998, the political scientist David Robertson claimed that the then House of Lords 'do not seem, truly, to think in terms of rights, but of priorities, needs, of discretionary solutions' ${ }^{17} \mathrm{He}$ described the court as exercising the role of manager - or referee - of the welfare state ${ }^{18}$ and, specifically, being highly sympathetic to the position of local authorities. ${ }^{19}$ Robertson's case is that the court was highly attuned to local authorities' arguments about the scarcity of resources and this attitude inappropriately pervaded their interpretation of the statute, and minimised its scope. It is possible to see vestiges of this approach, ${ }^{20}$ but that thesis does not adequately explain current jurisprudence. Indeed, some recent decisions are likely to have a significant adverse impact on local housing authorities' resources. ${ }^{21}$ Instead, the focus has shifted to refraining from over-judicialisation to avoid wasting public money on unnecessary adjudication.

The jewel in the crown of homelessness assistance is the so-called full housing duty, for which applicants must be eligible, unintentionally homeless, in priority need ${ }^{22}$ and not have a 'local connection' with another local authority. ${ }^{23}$ The criteria are set out in primary and secondary legislation, supplemented by statutory guidance ${ }^{24}$ to which front line decision-makers must have regard. ${ }^{25}$ To add further complexity, the statutory homelessness framework intersects with local authorities duties to adults with needs for care and support, ${ }^{26}$ their child safeguarding duties ${ }^{27}$ as well as Equality Act requirements. ${ }^{28}$ The statutory provisions are characterised by inherently vague language; for example, whether an applicant is 'vulnerable' for the purpose of being in priority need. ${ }^{29}$ It is, therefore, unsurprising that a significant body of case law has developed in order to clarify their application. While the terms are open to interpretation, only one provision allows local authorities to judge an applicant's situation against local conditions in order to determine whether he or she is not intentionally homeless. ${ }^{30}$ Furthermore, resource-based arguments are generally irrelevant: once the applicant has met the criteria, an absolute, legally enforceable right arises $^{31}$ albeit that authorities have flexibility in discharging that duty. ${ }^{32}$ It is important for the scheme to operate reasonably consistently across local authorities to avoid a postcode lottery of

\footnotetext{
${ }^{14}$ Housing (Homeless Persons) Act 1977.

${ }^{15}$ Department of the Environment Circular No 18/74 (London: HMSO, 1974).

${ }^{16}$ Hansard HC Deb, vol 936, col 882, 27 July 1977, Stephen Ross.

${ }^{17}$ D Robertson Judicial Discretion in the House of Lords (Clarendon, 1998) p 349.

${ }^{18}$ Ibid.

${ }^{19}$ Ibid, p 341.

${ }^{20}$ Above $\mathrm{n} 7$.

${ }^{21}$ Loveland, above n 6, and A Arden 'All change - the Supreme Court in 2014-2015' (2015) JHL 79.

${ }^{22}$ Housing Act 1996, s 193.

${ }^{23}$ Housing Act 1996, s 198.

${ }^{24}$ Ministry of Housing, Communities and Local Government Homelessness Code of Guidance for Local Authorities (February 2018). MHCLG considers the online version of the Code to be the most authoritative. It is available at https:// www.gov.uk/guidance/homelessness-code-of-guidance-for-local-authorities (accessed 26 May 2020).

${ }^{25}$ Housing Act 1996, s 182.

${ }^{26}$ Care Act 2014.

${ }^{27}$ Children Act 1989, ss 17 and 20. See also duties under the Children (Leaving Care) Act 2000.

${ }^{28}$ Equality Act 2010, ss 4, 13, 19 and 149.

${ }^{29}$ Housing Act 1996, s 189.

${ }^{30}$ Housing Act 1996, s 175(3).

${ }^{31}$ Hotak v Southwark London Borough Council [2015] UKSC 30.

${ }^{32}$ Housing Act 1996, ss 206 and 208. 
provision. This point is particularly salient because of the requirement for the applicant to have a 'local connection' with the area in which they are applying. ${ }^{33}$

The homelessness provisions therefore differ from the framework that regulates the allocation of social housing via the so-called waiting list. ${ }^{34}$ There, authorities undertake an assessment of relative need, with applicants competing with others on the list for a finite resource. Since 1996 the outcomes for each route are also different. Successful waiting list applicants receive a social housing tenancy, often of unlimited duration. By contrast, authorities can discharge their duty to successful homeless applicants through a private sector tenancy of a minimum 12 months' duration ${ }^{35}$ which may be outside their area ${ }^{36}$ and sometimes a considerable distance away; ${ }^{37}$ in other words, through an unlimited pool of housing, albeit that using private sector accommodation is extremely costly for local authorities. ${ }^{38}$ During homelessness law's formative years, it was generally understood that both routes led to the same outcome (ie access to a secure, public sector tenancy), with the consequence that both categories of applicants were in competition with each other for a finite resource. In these circumstances it is understandable that a generally highly deferential judicial approach was adopted, as described by Robertson. In the intervening period, however, much has changed. Homelessness duties have been formally separated from housing allocation functions and homelessness-related law has proliferated, as explained above. In reality, therefore, housing officers must have comprehensive understanding of a complex body of law in order to make lawful decisions. To characterise these decisions as administrative and discretionary is misleading, where that reasoning is used to justify the court adopting a more lenient approach to reviewing the lawfulness of authorities' decision-making.

\section{PDR and over-judicialisation}

PDR dominated administrative justice debates after its adoption by the Blair government in $2004 .{ }^{39}$ Its core tenet is simple to state and its aims laudable: 'there should be no disproportionate barriers to users in terms of cost, speed or complexity, but misconceived or trivial complaints should be identified and rooted out quickly. ${ }^{40}$ There was no intention that all decisions should be subject to full-scale legal representation at the taxpayer's expense because it 'would be disproportionate and unreasonable'. ${ }^{41}$ Disputes should be resolved 'quickly, effectively, and by the most relevant and appropriate means ${ }^{42}$ within the broader understanding that the administrative justice system should work effectively 'for its users and for the taxpayers who fund it'. ${ }^{43}$ Thus, PDR exposes the tensions inherent within administrative justice between efficiency, cost and individual justice. ${ }^{44}$ Borrowing from Elliott and Thomas, the question can be posed in these terms: what is the acceptable degree of legal error that should be tolerated by the reviewing court in the interests of the efficient - proportionate - use of judicial resources? ${ }^{45}$

\footnotetext{
${ }^{33}$ Housing Act 1996, s 198.

${ }^{34}$ Housing Act 1996, Pt VI.

${ }^{35}$ Housing Act 1996, s 206.

${ }^{36}$ Housing Act 1996, s 208 and the Homelessness (Suitability of Accommodation) (England) Order 2012, SI 2012/2601.

${ }^{37} \mathrm{cf}$ Nzolameso $v$ Westminster City Council [2015] UKSC 22.

${ }^{38}$ See the various reports cited in HC Library 'Households in temporary accommodation (England)' Research Briefing No 0211010 February 2020, pp 7-8.

${ }^{39}$ Department for Constitutional Affairs Transforming Public Services: Complaints, Redress and Tribunals Cm 6243 (July 2004) para 2.2. Lord Woolf employed the concept of proportionality in his report into civil justice: Lord Woolf Access to Justice: Interim Report (Lord Chancellor's Department, 1995) and Lord Woolf Access to Justice: Final Report (Lord Chancellor's Department, 1996).

${ }^{40} \mathrm{DCA}$, above n 39, para 1.7 .

${ }^{41}$ Ibid, para 10.3 .

${ }^{42}$ Ministry of Justice Administrative Justice and Tribunals: Final report of progress against the Strategic Work Programme 2013-2016 Cm 9310 (March 2017) p 30.

${ }^{43}$ Ibid, p 5.

${ }^{44}$ E Laurie 'Assessing the Upper Tribunal's potential to deliver administrative justice' (2012) PL 288 at 291.

${ }^{45} \mathrm{M}$ Elliott and R Thomas ‘Tribunal justice and proportionate dispute resolution' (2012) CLJ 297 at 299.
} 
Wikeley has observed that PDR prioritises Mashaw's ${ }^{46}$ bureaucratic rationality model, which stresses the administrative in administrative justice, over the legal model with its emphasis on the justice element. ${ }^{47}$

The Law Commission was charged with considering the application of PDR in the housing context. ${ }^{48}$ Its initial proposal - to transfer jurisdiction for homelessness adjudication from the county court to the then newly created Upper Tribunal ${ }^{49}$ - was not pursued in light of consultation responses expressing disquiet that the Upper Tribunal would prove less accessible to applicants. The Commission noted the trade-off between the ready accessibility of the county court, versus the ability of the Upper Tribunal, as a superior court of record, to improve and clarify homelessness law and practice. ${ }^{50}$ Far from de-judicialising homelessness adjudication, the Commission advocated its transfer to a higher judicial level in order to secure improvements to the law. It is therefore ironic that less than a year later the Supreme Court first urged the benevolent approach to homelessness reviews, implicitly emphasising the resource-efficient version of PDR.

The current statutory two-stage review process for homelessness decisions was introduced in $1997^{51}$ and so predates the formal PDR agenda. It can nevertheless be viewed as a forerunner to it. It was instigated following a Law Commission report and simultaneous government action which recommended the creation of a right of appeal to a court or independent tribunal for homelessness cases, preceded by an internal review. ${ }^{52}$ These steps were taken after the claimed 'explosion' of judicial review in immigration and homelessness cases ${ }^{53}$ which had led Lord Brightman to instruct that 'great restraint' should be exercised when giving leave to proceed in such cases. ${ }^{54}$ Lord Brightman was impatient with the use of judicial review to challenge local authorities which were 'endeavouring, in extremely difficult circumstances, to perform their [homelessness] duties': ${ }^{55}$ a view 'emphatically' endorsed by Lord Roskill. ${ }^{56}$ While the Law Commission approved the introduction of an internal review stage, ${ }^{57}$ it endorsed the view of the Council on Tribunals ${ }^{58}$ that it was not a substitute for a right of appeal to a court or independent tribunal. ${ }^{59}$

The internal review, which must be carried out by a more senior housing officer than the one who made the original decision, ${ }^{60}$ is a full merits appeal at which the applicant is entitled to make representations and to be represented. ${ }^{61}$ As will be discussed, these procedural safeguards were an important factor in the ECtHR's approval of the two-stage review process as being Article 6 compliant. If the applicant wishes to challenge the review decision, he or she may appeal to the county court on a point of law. ${ }^{62}$ The scope of this second stage is whether the original decision was one that the decision maker was entitled to reach $^{63}$ and is therefore equivalent to judicial review, which it replaced. ${ }^{64}$

\footnotetext{
${ }^{46}$ JL Mashaw Bureaucratic Justice (New Haven: Yale University Press, 1983).

${ }^{47} \mathrm{~N}$ Wikeley 'Future directions for tribunals: a UK perspective' in R Creyke (ed) Tribunals in the Common Law World (Sydney: The Federation Press, 2008) p 182.

${ }^{48}$ DCA, above n 39, para 2.4.

${ }^{49}$ Law Commission Housing: Proportionate Dispute Resolution Consultation Paper No 180 (20 March 2006) para 3.71.

${ }^{50}$ Law Commission Housing: Proportionate Dispute Resolution Law Com No 309 (May 2008) para 5.97.

${ }^{51}$ Housing Act 1996, ss 202-204.

${ }^{52}$ Law Commission Administrative Law and Statutory Appeals Law Com No 226 (October 1994) para 2.26.

${ }^{53}$ Ibid, para 1.11

${ }^{54}$ Puhlhofer $v$ Hillingdon London Borough Council [1986] AC 484 at 518.

${ }^{55}$ Ibid, at 518 .

${ }^{56} \mathrm{Ibid}$, at 510 .

${ }^{57}$ Law Commission, above n 52, para 2.24 .

${ }^{58}$ Council on Tribunals Annual Reports 1989/90 cited in Law Commission, above n 52, para 2.18.

${ }^{59}$ Law Commission, above n 52, para 2.25.

${ }^{60}$ Housing Act 1996, ss 202 and 203 and the Homelessness (Review Procedure etc) Regulations 2018, SI 2018/223 which replace the Allocation of Housing and Homelessness (Review Procedures) Regulations 1999, SI 1999/71.

${ }^{61}$ Ibid, reg 5(3).

${ }^{62}$ Housing Act 1996, s 204.

${ }^{63}$ Danesh $v$ Kensington and Chelsea [2006] EWCA Civ 1404 at [30] per Lord Neuberger.

${ }^{64}$ Runa Begum, above n 4. 
Compulsory internal review - or administrative review ${ }^{65}$ - is now a common feature of welfare administrative decision-making both in the $\mathrm{UK}^{66}$ and further afield ${ }^{67}$ and it has obvious attraction for governments pursuing an agenda of efficiency and cost-savings. ${ }^{68}$ As a facet of PDR, it scores highly for speed, efficiency and accessibility but poorly for independence. Cowan et al have argued that internal review can act as a valuable mechanism to improve front-line decision-making. ${ }^{69}$ Nevertheless, Tribunal judges within the social security context have expressed scepticism about the thoroughness of mandatory reconsideration. ${ }^{70}$ Furthermore, noting the steep drop in the volume of social security appeals following its introduction, Thomas and Tomlinson highlight the concern that many cases which could succeed before tribunals fall away after the mandatory reconsideration stage. As they observe: ' $t$ ] his creates the impression that the [Department for Work and Pensions] is gatekeeping the tribunals system and taking advantage of claimant fatigue ${ }^{, 71}$ principally to save money. ${ }^{72}$

On its own it is incompatible with Article 6 of the ECHR since it lacks the requisite independence. ${ }^{73}$ However, as discussed below, by recognising the goal of efficiency as a legitimate feature of the homelessness review process, the ECtHR held that the current two-stage process is Article 6 compliant. ${ }^{74}$ At a broader level, Thomas and Tomlinson claim that the growth in administrative review 'has gone hand-in-hand with a correspondingly smaller role for the judicial control of front-line administrative decisions, ${ }^{75}$ at the cost of individual redress. ${ }^{76}$ Controversially, in 2014, existing immigration appeal rights (except on asylum and human rights grounds) were replaced with administrative review ${ }^{77}$ with an anticipated cost-saving of $£ 261$ million over 10 years. ${ }^{78}$ Thus, mandatory internal review, as a condition of accessing independent review, represents a conscious policy choice to prioritise efficiency and cost-saving over individualised justice. Consequently, in contrast to the claimed 'juristocracy' which dominates debates, important areas of administrative law have witnessed significant de-judicialisation. ${ }^{79}$

No official statistics are gathered on either the first or second stages of review. ${ }^{80}$ This omission is problematic because it hinders the valuable scrutiny undertaken in other areas of administrative decision-making. ${ }^{81}$ To give some indication of the volume of appeals to the county court - the judicial stage - official statistics show that in 2018 local authorities made 109,470 decisions on applications, approximately $50 \%$ of which were found to be owed the full housing duty. ${ }^{82}$ Consequently, around $50 \%$ of applications were unsuccessful. Additionally, applicants who are dissatisfied with the

\footnotetext{
${ }^{65} \mathrm{R}$ Thomas and J Tomlinson 'A different tale of judicial power: administrative review as a problematic response to the judicialisation of tribunals’ (2019) PL 537.

${ }^{66}$ It was introduced in the social security context in 2013: Welfare Reform Act 2012, s 102, which amended Social Security Act 1998, s 12.

${ }^{67}$ For example Australia: see D Cowan et al The Appeal of Internal Review (Oxford: Hart Publishing, 2004) p 4.

${ }^{68}$ Cowan et al, above n 67, p 5; R Thomas and J Tomlinson 'Remodelling social security appeals (again): the advent of online tribunals' (2018) JSSL 84 at 86.

${ }^{69} \mathrm{D}$ Cowan et al 'Reconsidering mandatory reconsideration' (2017) PL 215.

${ }^{70} \mathrm{P}$ Gray The Second Independent Review of the Personal Independence Payment Assessment (TSO, 2017) para 29.

${ }^{71}$ Thomas and Tomlinson, above $\mathrm{n} 68$, at 86.

${ }^{72}$ Thomas and Tomlinson, above n 65, at 537.

${ }^{73}$ Ali v UK App No 40378/10 ECtHR, 20 October 2015 [2015] HLR 46.

${ }^{74}$ Ibid.

${ }^{75}$ Thomas and Tomlinson, above n 65, at 538.

${ }^{76}$ Ibid.

${ }^{77}$ Immigration Act 2014, s 15 substituting Nationality, Immigration and Asylum Act 2002, s 82.

${ }^{78}$ Home Office Impact Assessment of Reforming Immigration Appeal Rights (TSO, 2013) p 2.

${ }^{79}$ Thomas and Tomlinson, above n 65 .

${ }^{80}$ J Luba HHJ QC 'The Bryan McGuire QC Memorial Lecture: Known unknowns: dispute resolution in homelessness' (2017) JHL 86 at 90.

${ }^{81}$ For example, social security and immigration: see Thomas and Tomlinson above $\mathrm{n} 65$.

${ }^{82}$ Live tables on Homelessness Table 784, available at https://www.gov.uk/government/statistical-data-sets/live-tables-onhomelessness\#statutory-homelessness-live-tables (accessed 26 May 2020). 
accommodation they are offered may also initiate a review. A Circuit Judge of the central London county court, which deals with all the London homeless appeals, has estimated that the court receives 40-60 appeals each month. ${ }^{83}$ Given that London authorities accepted $15,470^{84}$ households as owed the full duty, and working on approximately $50 \%$ failure rate, we can estimate a second-stage review rate of roughly $4.6 \% .{ }^{85}$ Cowan et al have conducted empirical research into mandatory internal review as a feature of homelessness adjudication, and the rough-and-ready calculation offered here is supported by that data, gathered on five occasions between 1998 and 2015, which indicates that that 'homelessness law is no different from most other areas of the administrative justice system whereby we see radical drop-off rates between initial applications, internal reviews and subsequent appeals' ${ }^{86}$ The absolute numbers seeking a second review are relatively low, militating against a claim of overjudicialisation where that phrase relates to volume of cases.

In this respect, the senior judiciary appear to have somewhat different foci. For Lord Bingham, the danger was 'the emasculation (by over-judicialisation) of administrative welfare schemes ... ${ }^{87}$ which appears to emphasise the effectiveness of the scheme. By contrast, Lord Hoffmann, Lord Hope and Lord Carnwarth seem more concerned with the objective of not wasting public money on an unduly judicialised process which, as explained earlier, is resonant with the PDR concept. As Lord Hoffmann noted, 'Parliament is entitled to take the view that it is not in the public interest that an excessive proportion of the funds available should be consumed in administration and legal disputes' ${ }^{88}$ This is, of course, true and whether the amount spent on decision-making and adjudication is excessive depends on one's view of where the correct balance lies between the interests of the individual and those of society as a whole: a question to which there is no correct answer and about which views may legitimately differ. ${ }^{89}$ My contention is that Parliament has legislated to incorporate significant elements of PDR in the homelessness scheme: mandatory administrative review and independent appeal limited to a point of law. It is thus inappropriate for the senior judiciary to create an additional barrier to individuals' access to justice by instructing courts to adopt a benevolent approach to interpreting review decisions.

The next section first explains the origin of the benevolent approach and then examines the research into the quality of front-line decision-making which, it is argued here, undermines claims that local authorities' experience justifies giving them the benefit of the doubt when reviewing the legality of their decisions. This discussion is followed by an analysis of the cases where the Supreme Court has departed from the benevolent approach to scrutinise intensely certain decisions.

\section{The origin of the benevolent approach}

Since the creation of the statutory homeless scheme, authorities have been required to provide reasons for their adverse decisions ${ }^{90}$ or, since 1997, adverse review decisions ${ }^{91}$ and courts have debated the appropriate level of judicial scrutiny. There is agreement in principle that the reasons must be sufficient to enable the applicant to judge whether the decision may be legally challenged ${ }^{92}$ but the case law reveals disagreement when applied to individual facts. For example, in $\mathrm{Graham}^{93}$ the majority in the

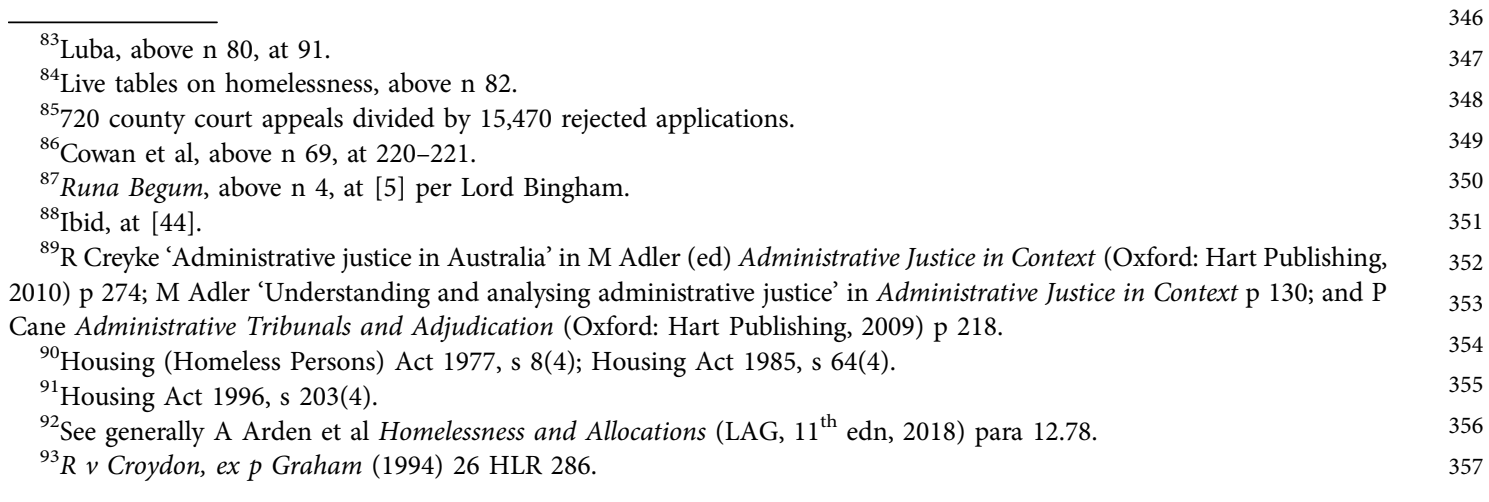


Court of Appeal ${ }^{94}$ (with Hoffmann LJ dissenting) overturned the district judge on the adequacy of the authority's reasoning. Sir Thomas Bingham agreed with counsel for the authority that a 'pedantic exegesis' of the review letter would be inappropriate but nevertheless insisted that the duty to provide reasons meant reasons that are 'intelligible and which convey to the applicant the reasons why the application has been rejected in such a way that if they disclose an error of reasoning the applicant may take such steps as may be indicated'. ${ }^{95}$ Conversely in Hinds, the Court of Appeal overturned the district judge, commenting that 'If a Housing Authority were required to go through the elaborate reasoning process proposed by the judge it would impose an impractical and undue burden upon them' ${ }^{96}$ Holmes-Moorhouse was the first occasion the House of Lords (as it then was) expressed a view on the correct balance. Having observed that the responsibility placed on the county court judge is 'heavy', because of the need to ensure that the applicant is not unfairly deprived of benefits that he or she was intended to receive, Lord Neuberger nevertheless proceeded to instruct the lower courts that:

[A] benevolent approach should be adopted to the interpretation of review decisions. The court should not take too technical view of the language used, or search for inconsistencies, or adopt a nit-picking approach, when confronted with an appeal against a review decision. That is not to say that the court should approve incomprehensible or misguided reasoning, but it should be realistic and practical in its approach to the interpretation of review decisions. (emphasis added) ${ }^{97}$

The specific issue was an acknowledged error in one paragraph of the review decision. The Circuit Judge considered that the mistake did not affect the lawfulness of the decision as a whole but this point was overturned by the Court of Appeal and hence Lord Neuberger's criticism was aimed at that court. He observed that while housing officers had considerable experience, they were not lawyers and so their decisions should not be subjected to the same scrutiny as a contract drafted by solicitors, Act of Parliament or court judgment. ${ }^{98}$

The general proposition that judges should refrain from taking an overly technical approach is reasonable but, as Lord Neuberger identified, the judge is in the difficult position of ensuring sufficiently rigorous review to avoid the applicant being unlawfully denied their rights but without overstepping a theoretical line into nit-picking. It is clear that judges disagree on where that balance lies when applied to specific facts. ${ }^{99}$ At the very least, the benevolent approach implies giving local authorities the benefit of the doubt but it is difficult to gauge the extent to which district judges do so, as no statistics on appeals and success rates are gathered, as explained earlier. On the wider issue of judicial oversight of cases involving resource allocation, just a month after Holmes-Moorhouse Lord Neuberger took the opportunity to express a similar position regarding local authorities' housing allocation duties. ${ }^{100}$ Once again overturning the Court of Appeal, he stated that, 'as a general proposition, it is undesirable for the courts to get involved in questions of how priorities are accorded'. ${ }^{101}$ His reasoning mirrors that in Holmes-Moorhouse; in particular local authorities' expertise in the subject. ${ }^{102}$ It is of course possible to read too much into these two statements but it does appear that Lord Neuberger is advocating less intensive judicial scrutiny which, it is argued here, is wrong in principle.

\footnotetext{
${ }^{94}$ Hoffmann LJ dissented.

${ }^{95}$ Graham above $\mathrm{n} 93$, at 292.

${ }^{96} R$ v Islington London Borough Council, ex p Hinds (1996) 28 HLR 302.

${ }^{97}$ Holmes-Moorhouse, above n 7, at [50].

${ }^{98}$ Ibid, at [47].

${ }^{99}$ See also Ibrahim $v$ Wandsworth London Borough Council [2013] EWCA Civ 20, [2013] HLR 15.

${ }^{100} R$ (Ahmad) $v$ London Borough of Newham [2009] UKHL 14, [2009] HLR 31.

${ }^{101}$ Ibid, at [46].

${ }^{102} \mathrm{Ibid}$, at [46] and [62].
} 
Disagreement over the intensity of review is not limited to the homelessness context. In his analysis of asylum appeals, Thomas observes that 'there is the risk ... that the reviewing judge's search for adequate reasons can easily become a quixotic search for decisional perfection'. ${ }^{103}$

\section{The quality of decision-making and internal reviews}

A significant body of academic research into homelessness decision-making has consistently highlighted its variable quality. Unlawful practices have also been identified by the courts, the Local Government Ombudsman, ${ }^{104}$ housing practitioners ${ }^{105}$ and the media. ${ }^{106}$ Writing in 1995 , Loveland found that 'many of the procedures that councils follow and many of the substantive conclusions that they reach ... may be unlawful'. ${ }^{107}$ This conclusion has been reached by others, with Hunter finding that it is not uncommon for local authorities to make inconsistent and unlawful decisions that remain unchallenged by applicants. ${ }^{108}$ Poor quality front-line decision-making is also a consistent concern in the social security and immigration contexts, ${ }^{109}$ thus increasing the importance of independent review in order to secure individual redress and to achieve broader goals of administrative justice.

Unsurprisingly the research has found that housing officers are subject to a range of sometimes competing influences when applying the homelessness law, including financial management, performance audit, ${ }^{110}$ sometimes referred to as a target culture, ${ }^{111}$ political pressure, in addition to personal and 'intersubjective' factors. Halliday's research found that housing officers developed a socially constructed, professional intuition for the 'real story' behind the homelessness application which informed how the case progressed. ${ }^{112}$ In one local authority there was a 'culture of suspicion' that homeless applicants changed their stories in order to gain access to housing. ${ }^{113}$ In another authority, racial stereotyping was evident. ${ }^{114}$

A recurring theme within the case law and the literature is the need to ration a scarce resource - a phenomenon pre-dating the current climate of austerity but exacerbated by it. In this regard, there is an important - but difficult - distinction between homelessness prevention, which local authorities are statutorily obliged to undertake, ${ }^{115}$ and unlawful gatekeeping practices. Gatekeeping can take a number of forms, including: failing to take an application for assistance; making an appointment for a date in the future for a homeless application to be taken; referring an applicant to another organisation (for example, a charity or a housing association $)^{116}$ or to another local authority; and making an immediate negative decision without making proper inquiries. ${ }^{117}$ Evans' research in the 1990 s found that staff

\footnotetext{
${ }^{103} \mathrm{R}$ Thomas Administrative Justice and Asylum Appeals: A Study of Tribunal Adjudication (Oxford: Hart Publishing, 2011) p 262.

${ }^{104}$ Local Government Ombudsman Homelessness: How Councils Can Ensure Justice for Homeless People (2011).

${ }^{105} \mathrm{G}$ Peaker 'Gatekeeping in times of austerity' (2012) JHL 107.

${ }^{106} \mathrm{H}$ Summers 'Homeless women turned away by local councils "trying to keep numbers down"' (The Independent, 12 February 2017).

${ }^{107}$ I Loveland Housing Homeless Persons: Administrative Law and Process (Clarendon Press, 1995) p 302.

${ }^{108} \mathrm{C}$ Hunter 'Denying the severity of mental health problems to deny rights to the homeless' (2007) 2(1) People, Place and Policy Online 18.

${ }^{109} \mathrm{R}$ Thomas and J Tomlinson 'Mapping current issues in administrative justice: austerity and the "more bureaucratic rationality” approach' (2017) JSWFL 39380

${ }^{110}$ S Halliday Judicial Review and Compliance with Administrative Law (Oxford: Hart Publishing, 2004) p 87.

${ }^{111}$ S Alden 'On the frontline: the gatekeeper in statutory homelessness services' (2015) 30(6) Housing Studies 924 at 931.

${ }^{112} \mathrm{~S}$ Halliday 'Institutional racism in bureaucratic decision-making: a case study in the administration of homelessness law' (2000) 27(3) JLS 449.

${ }^{113}$ Ibid, at 464. See also D Cowan Homelessness: The (In-) Appropriate Applicant (Ashgate, 1997).

${ }^{114}$ Halliday, above n 112 , at 457.

${ }^{115}$ Homelessness Act 2002, ss 1-3.

${ }^{116}$ See $R$ (on the application of Khazi) $v$ Birmingham City Council [2010] EWHC 2576 (Admin).

${ }^{117} \mathrm{Z}$ Nabi 'Gatekeeping: lessons from the Birmingham cases' (2012) JHL 109 at 110.
} 
routinely discouraged applications from single people. ${ }^{118}$ An example is provided by Robinson in which the housing officer turned away a 17 year old (who would automatically be in priority need) on the basis that the local authority's enquiries into her application would take 28 days, by which time the applicant would be 18 , and would then only be in priority need if she were vulnerable. ${ }^{119}$ Waller LJ described the action as 'illegitimate ${ }^{120}$ and was equally unimpressed with the authority's subsequent attempt to avoid its duty by trying to persuade the applicant and her family to undergo mediation. ${ }^{121}$

The Local Government Ombudsman has highlighted similar instances of gatekeeping, ${ }^{122}$ and Niner's research revealed tactics such as requesting substantial amounts of evidence to support claims, or advising an applicant that they would be likely to be found intentionally homeless, in a bid to dissuade potential applicants. ${ }^{123}$ Another unlawful gatekeeping technique is to alter the threshold for an applicant to be considered vulnerable and therefore to be in priority need. Halliday's research found that this practice was employed by one local authority, in direct response to the need to make financial savings. ${ }^{124}$

Indeed, the need to meet government targets on reducing homelessness acceptances and the cut in local authorities' annual budgets by central government are identified as the primary motivations for unlawful gatekeeping, although poor staff training is often a contributory factor. ${ }^{125}$ In terms of a target culture, research published in 2005 found evidence to suggest that housing law was repeatedly and flagrantly broken due to the pressure to meet organisational objectives. ${ }^{126}$ Alden's recent research focuses specifically on whether gatekeeping practices have increased as a result of the austerity agenda, which has had a particularly adverse effect on local authorities' budgets: ${ }^{127}$ the National Audit Office reports a reduction of nearly $50 \%$ since $2010-11 .{ }^{128}$ Unsurprisingly, the research reveals that gatekeeping practices had worsened, leading the author to conclude that 'frontline workers were required to contravene policy in order to satisfy central policy goals. ${ }^{129}$ Prevention duties have been expanded and strengthened under the Homelessness Reduction Act 2017 and it is essential that unlawful gatekeeping is checked to ensure that the Act benefits homeless people in the way it is intended.

Saliently, adequate training of housing officers has also become a victim of austerity. ${ }^{130}$ The degree of legal knowledge and legal conscientiousness of decision-makers has been found by Halliday to explain the gap between the law and routine practice. ${ }^{131}$ One research study countering the pervasive findings of unlawful practices concerns the determination of a person's vulnerability. In their study of three local authorities, Hunter et al found 'a small oasis of consistent legal compliance' on this issue. ${ }^{132}$ Their conclusion is unusual considering the body of research discussed above, and case law on the specific point. For example, in Hotak, Lord Neuberger described as 'plainly wrong' one local

\footnotetext{
${ }^{118}$ A Evans 'Rationing device or passport to social housing? The operation of the homelessness legislation in Britain in the 1990s' in S Hutson and D Clapham (eds) Homelessness: Public Policies and Private Troubles (Cassell, 1999) pp 133-154 cited in Alden, above n 111.

${ }^{119}$ Robinson $v$ Hammersmith and Fulham London Borough Council [2006] EWCA Civ 1122, [2007] HLR 7 at [2] per Waller LJ.

${ }^{120}$ Ibid, at [38].

${ }^{121} \mathrm{Ibid}$, at $[41]$.

${ }^{122}$ Local Government Ombudsman, above n 104. See also eg LGO Decision 09001262.

${ }^{123}$ P Niner Homelessness in Nine Local Authorities: Case Studies of Policy and Practice (HMSO, 1989) cited in Alden, above n 111.

${ }^{124}$ Halliday, above n 112 , at 456.

${ }^{125} \mathrm{Nabi}$, above $\mathrm{n} 117$, at 110 .

${ }^{126} \mathrm{~B}$ Rashleigh 'Keeping the numbers down' (2005) ROOF cited in Alden, above n 111.

${ }^{127}$ Alden, above n 111.

${ }^{128}$ National Audit Office Financial Sustainability of Local Authorities HC 834 Session 2017-19 8 March 2018.

${ }^{129}$ Alden, above n 111 , at 938 .

${ }^{130} \mathrm{Ibid}$, at 936

${ }^{131}$ Halliday, above n 110 .

${ }^{132} \mathrm{C}$ Hunter et al 'Legal compliance in street-level bureaucracy: a study of UK housing officers' (2016) 38(1) Law \& Policy 81 at 82 . 
authority's misapplication of the vulnerability assessment. ${ }^{133}$ The finding of legal compliance is ironic in light of a recent Supreme Court decision which has altered the long-standing test of vulnerability, ${ }^{134}$ thus potentially causing confusion and scope for inadvertently unlawful decision-making.

The degree of unlawful decision-making revealed by the research substantially undermines the justification for the courts' general instruction to adopt a benevolent approach to review decisions, if founded on authorities' experience and therefore institutional competence. It has already been contended that although the statutory homelessness provisions incorporate discretion, the body of law with which housing officers must comply is both voluminous and complex. This point is demonstrated in the following section through an analysis of key Supreme Court decisions.

\section{Unpredictability in the Supreme Court}

A further facet of the argument against the benevolent approach is the Supreme Court's own inconsistency; sometimes expressly departing from or qualifying the application of a benevolent approach and in other situations implicitly adopting a more rigorous approach. These cases are analysed below to discern whether there is a unifying justification for this more forensic scrutiny. Relatedly, Cowan has drawn attention to the Court of Appeal's unpredictability when adjudicating on the regulations governing the internal review process, which was explained above. ${ }^{135}$

In 2015, the Supreme Court considered how the Public Sector Equality Duty (PSED) affected local authorities' homelessness decision-making. In Hotak the appellant argued that the reviewing officer had paid insufficiently careful or critical attention to his disability and to the consequences of a decision that he was not vulnerable under the homelessness provisions. ${ }^{136}$ The author of the Holmes-Moorhouse principle, Lord Neuberger, said that in these cases the general principle had to be applied in light of the need to 'focus very sharply' on the complementary equality duty. ${ }^{137}$ Thus, a lawful approach should avoid 'formulaic and high-minded mantras ${ }^{\text {'138 }}$ and he rejected the argument that the PSED added nothing to the intensity of the review. ${ }^{139}$ Lord Neuberger's judgment creates an explicit exception and seems to suggest that county court judges should not accept bland assertions in review decisions that the PSED has been considered. However, a subsequent Court of Appeal deci$\operatorname{sion}^{140}$ criticised a highly experienced county court judge ${ }^{141}$ for applying 'an inappropriately rigid standard for the purpose of giving reasons sufficient to demonstrate compliance with the PSED'. ${ }^{142}$ By contrast, a later and differently constituted Court of Appeal has applied a more rigorous standard of review, criticising the local authority housing officer for failing to differentiate between the applicant's particular needs, arising from her disability, and those of the general population on its housing waiting list. ${ }^{143}$ We are therefore left with an uncertain picture in the lower and appellate courts of the appropriate standard of review in these cases.

A more rigorous review was also undertaken in Nzolameso, where children were involved ${ }^{144}$ and the local authority was providing housing outside its area. ${ }^{145}$ In the context of deciding to secure

\footnotetext{
${ }^{133}$ Hotak, above n 31, at [45].

${ }^{134}$ Ibid.

${ }^{135} \mathrm{D}$ Cowan 'The judicialisation of homelessness law: a study of regulation 8(2), Allocation of Housing and Homelessness (Review Procedures) Regulations 1999’ (2016) PL 235.

${ }^{136}$ Hotak, above n 31, at [72].

${ }^{137}$ Ibid, at [79].

${ }^{138}$ Ibid, at [78]-[79].

${ }^{139}$ Ibid, at [79].

${ }^{140}$ Hackney London Borough Council v Haque [2017] EWCA Civ 4, [2017] HLR 14 at [8]-[9].

${ }^{141}$ Luba HHJ QC.

${ }^{142}$ Haque, above n 140, at [51].

${ }^{143}$ Wendy Lomax v Gosport Borough Council [2018] EWCA Civ 1846 at [48]-[50].

${ }^{144}$ The local authority must discharge its functions 'having regard to the need to safeguard and promote the welfare of children': Children Act 1989, s 11(2).

${ }^{145}$ Homelessness (Suitability of Accommodation) (England) Order 2012, SI 2012/2601, art 2.
} 
temporary housing for a family $1 \frac{1 / 4}{4}$ hours away from their previous home in Westminster, ${ }^{146}$ Lady Hale held that the inclusion in the review letter of a standard paragraph referring to the general shortage of housing in Westminster was insufficient to demonstrate compliance with the local authority's duty. ${ }^{147}$ It is noteworthy that the Secretary of State intervened to complain that the approach adopted at first instance and in the Court of Appeal was insufficiently rigorous. ${ }^{148}$ The Court of Appeal had taken the usual approach by reading the decision as a whole and assuming that the reviewing officer was aware of the resources available to the council and the pressures on them. Consequently, ' $i \mathrm{i}] \mathrm{t}$ is not necessary in a decision letter of this kind for the reviewing officer to describe in detail what those resources and pressures are. ${ }^{149}$ The Secretary of State protested that if this decision were upheld, it would encourage courts to infer, on no other basis than the assumed experience and knowledge of a local authority, that it had taken into account the required factors and had good reasons for their decision. The Secretary of State was concerned that this approach 'would immunise from judicial scrutiny the "automatic" decisions to house people far from their home district .... ${ }^{150}$ As will be explained, the government has been anxious to avoid the applicability of Article 6 to homelessness adjudication and so it seems paradoxical to urge greater scrutiny.

The courts' comment about avoiding over-judicialisation was made in the context of its denial of the applicability of Article 6 of the ECHR to homelessness decision-making and so is not explicitly linked to its admonition to adopt a benevolent approach. Nevertheless, I argue that they share a common root that over-emphasises the elements of local authority discretion, thereby diminishing the status of homelessness adjudication. The cases examined in this section - and the Supreme Court's interpretation of the statutory provisions - strongly militate against the argument of a predominantly discretionary scheme.

The imperative of reducing judicial costs is not limited to homelessness but applies across the administrative decision-making spectrum, and the widespread introduction of mandatory internal (administrative) reviews is a key measure in that regard. The next section analyses the relevant Article 6 case law to discern what members of the judiciary meant by over-judicialisation. Although homelessness was the specific focus, the potential for analogous arguments in other areas of administrative decision-making appears to have been a key motivating factor in the denial of Article 6.

\section{The application of Article 6}

Since the Human Rights Act 1998 came into force, a key question has been the extent to which Article 6 of the ECHR is engaged by administrative decision-making. ${ }^{151}$ There are two inter-related questions: does Article 6 apply and, if so, how can the requirement for an independent and impartial tribunal be satisfied? The issues are inextricably linked because the domestic courts have consistently maintained that the wider the engagement of Article 6, the more flexible the interpretation of independent and impartial' must be. Internal (administrative) review on its own is incompatible with Article 6 and consequently the focus has been the extent of the powers of the independent and impartial element of the composite procedure; specifically whether it must be able to conduct a full rehearing of the facts to be Article 6 compliant.

The early case law on homelessness decision-making preferred to assume that Article 6 was engaged, without addressing that issue directly. ${ }^{152}$ In Runa Begum, Lord Bingham rejected the

\footnotetext{
${ }^{146}$ Nzolameso $v$ Westminster City Council [2015] UKSC 22, [2015] HLR 22.

${ }^{147}$ Ibid, at [36]-[37].

${ }^{148}$ Ibid, at [35].

${ }^{149} \mathrm{Ibid}$, at $[21]$.

${ }^{150} \mathrm{Ibid}$, at [35].

${ }^{151}$ Konig $v$ Federal Republic of Germany (1978) 2 EHRR 170; Bentham $v$ The Netherlands (1985) 8 EHRR 1; Bryan $v$ United Kingdom (1995) 21 EHRR 342; Albert v Belgium (1983) 5 EHRR 533.

${ }^{152}$ Runa Begum, above n 4, at [6].
} 
argument that the duty owed to the homeless applicant by the local authority did not constitute a 'right' because the statutory scheme gave it a large measure of discretion. ${ }^{153}$ Nevertheless, the question remained as to whether it was also a civil right within the autonomous meaning of Article $6^{154}$ and that point was left open. The application of Article 6 was revisited by the Supreme Court in 2010 in $A l^{155}$ and, for the first time, it held that Article 6 was not engaged. Lord Hope emphasised the distinction between the payment of social security benefits, which have been accepted as being subject to Article $6,{ }^{156}$ and homelessness decisions. As far as the latter are concerned, he characterised them as a series of evaluative judgments as to whether the statutory criteria are met, which potentially lead to the award of services or benefits in kind. In his judgment, such cases 'do not engage art 6(1) [because they] do not give rise to "civil rights" .... ${ }^{157}$ Lord Hope reiterated Lord Hoffmann's words in Runa Begum in 2003 that there were areas of administrative decision-making where 'utilitarian considerations have their place' and that:

[I]t is not in the public interest that an excessive proportion of the funds available for schemes for the regulation of social welfare should be consumed in administration and legal disputes. ${ }^{158}$

Consequently, the court chose to focus on the discretionary elements of the process, rather than the individually legally enforceable right that ensues if the applicant fulfils the statutory criteria. ${ }^{159}$ In the subsequent appeal to Strasbourg, the ECtHR denied the Supreme Court's view that a benefit in kind cannot be a civil right for the purposes of Article 6, and it was immaterial that the appellant's entitlement to housing was subject to an exercise of discretion. ${ }^{160}$ The ECtHR nevertheless accepted that the current two-stage process was compatible with the requirements of Article 6, despite the county court's inability to examine disputed facts.

The Supreme Court subsequently rejected the ECtHR's decision that Article 6 was applicable. ${ }^{161}$ Lord Carnwath, giving the opinion of the court, was 'disappointed' that the ECtHR had failed to address the concerns about over-judicialisation and the consequences for local authority's resources. ${ }^{162}$ However, this criticism appears unjustified as the ECtHR summarised the Strasbourg jurisprudence as emphasising 'the respect which must be accorded to decisions taken by the administrative authorities on grounds of "expediency" ...' ${ }^{163}$ Furthermore, it acknowledged the homelessness scheme's policy objective as intending to bring as great a benefit as possible in an economical and fair manner, ${ }^{164}$ and endorsed the dicta of Thomas LJ in the Court of Appeal that requiring the county court appeal to be a full merits appeal would have significant implications for both the statutory scheme and the court and tribunal system. ${ }^{165}$ The ECtHR accordingly explicitly recognised cost and efficiency as relevant factors.

When assessing the scheme's compatibility with Article 6, the ECtHR emphasised the importance of the procedural protections; ${ }^{166}$ for example, the requirement for the reviewing officer to be more senior than the initial decision-maker and the opportunity for the claimant to make representations

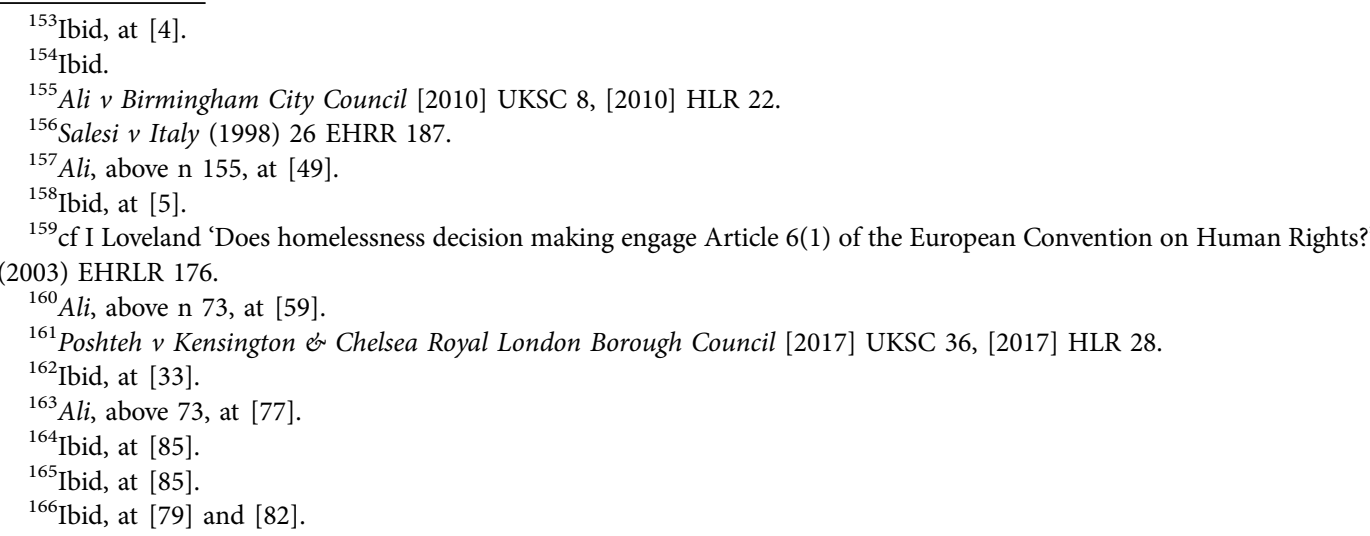


and to be represented. ${ }^{167}$ This focus on procedural safeguards is a recurring theme of the ECtHR's jurisprudence, as the Supreme Court is well aware through the protracted judicial tussle over the Strasbourg court's insistence on the presence of such measures in mandatory repossession cases by public landlords. ${ }^{168}$ There, the dispute centred on what was required for compatibility with Article 8 ECHR, with the Supreme Court eventually accepting the ECtHR's insistence on the availability of a proportionality review by the court to afford tenants a base level of protection. ${ }^{169}$ Thus, rather than contesting the ambit of Article 6 over fears of over-judicialisation, it is contended that the court (and the government) should focus on evaluating - and if necessary strengthening - the safeguards in place in mandatory internal (administrative) review. This reasoning applies with equal force across the spectrum of administrative decision-making and has already been recommended in the social security and immigration contexts. ${ }^{170}$

When considering the homelessness review process, the ECtHR did not refer to the Supreme Court's benevolent approach instruction. However, the argument made here is that it represents an additional, informal layer of PDR that elevates the importance of the internal review. It therefore potentially undermines the integrity of the composite process, both at the individual level and in the broader, collective sense and, consequently, the ECtHR's approval of it.

\section{Judicial creep}

The desire to conserve judicial resources is, of course, not limited to the homelessness context and it appears that the fear of 'judicial creep' into other spheres of administrative decision-making was an important factor for the government, which intervened in each of the homelessness cases to argue strongly against the applicability of Article $6 .{ }^{171}$ It is hard to discern a principled approach to the nature and extent of review or appeal rights across the range of administrative decisionmaking. ${ }^{172}$ Two were specifically mentioned during the course of litigation - social care and special educational needs ${ }^{173}$ - but immigration is most obviously vulnerable to challenge on human rights grounds since most appeal rights have been replaced by internal review, followed by the possibility of judicial review. ${ }^{174}$ The Care Act 2014 committed the government to develop an independent appeal system for adult social care ${ }^{175}$ but its implementation has been delayed until 2020. ${ }^{176}$ Consequently, challenges are limited to an internal review by the relevant local authority followed by the possibility of an application for judicial review. By contrast, the remit of the First-Tier Tribunal (Special Educational Needs and Disability) was extended in 2018 in a two-year pilot project to empower it to make recommendations about health and social care issues in all appeals, except refusal to secure an educational, health and care needs assessment or re-assessment. ${ }^{177}$ Equally, school admissions appeal panels ${ }^{178}$ are required to undertake a twostage decision-making process which involves not only verifying the legality of individual

\footnotetext{
${ }^{167}$ The Homelessness (Review Procedure etc) Regulations 2018, SI 2018/223, regs 5(3) and 8(2)(b).

${ }^{168}$ S Nield 'Clash of the titans: Article 8, occupiers and their home' in S Bright (ed) Modern Studies in Property Law Vol 6 (Oxford: Hart Publishing, 2011).

${ }^{169}$ Manchester City Council v Pinnock [2010] UKSC 45, [2011] 2 AC 10; Hounslow London Borough Council v Powell [2011] UKSC 8, [2011] 2 AC 186.

${ }^{170}$ Thomas and Tomlinson, above $\mathrm{n} 65$.

${ }^{171} \mathrm{Ali}$, above $\mathrm{n} \mathrm{155}$, at [4].

${ }^{172}$ Thomas and Tomlinson, above n 65, at 542.

${ }^{173} \mathrm{Ali}$, above $\mathrm{n} 155$, at [4].

${ }^{174}$ Immigration Act 2014, s 15 substituting Nationality, Immigration and Asylum Act 2002, s 82.

${ }^{175}$ Care Act 2014, s 72.

${ }^{176} \mathrm{MoJ}$, above n 9, p 17.

${ }^{177}$ The Special Educational Needs and Disability (First-tier Tribunal Recommendations Power) Regulations 2017, SI 2017/ 1306.

${ }^{178}$ Which undertake a judicial function; Department for Education School Admission Appeals Code Statutory Guidance for School Leaders, Governing Bodies and Local Authorities (February 2012) section 1.2.
} 
decisions but also undertaking a general balancing exercise of the school's refusal against the affected parent or child's wishes. ${ }^{179}$

The Supreme Court has also addressed judicial resource issues in social security adjudication. ${ }^{180}$ There, the question was the extent to which the (then) newly created Upper Tribunal should be susceptible to judicial review. ${ }^{181}$ Elliott and Thomas argued that the Supreme Court's reasoning was primarily influenced not by doctrinal considerations but by concerns of proportionate dispute resolution. ${ }^{182}$ Unsurprisingly, the government had argued for the Upper Tribunal to be immune to judicial review ${ }^{183}$ but that position was rejected by both the Court of Appeal and Supreme Court. Those courts' reasoning resonates not only in the homelessness context but throughout administrative decision-making. Lady Hale identified the risk of the Upper Tribunal developing 'local law', ${ }^{184}$ while Lord Dyson warned against the fossilisation of errors in principle or practice without sufficient oversight. ${ }^{185}$ As the Court of Appeal in Cart observed, the government has just as much interest in justice being done in the individual case, even if its first instinct is towards efficiency and cost-effectiveness, to ensure integrity of administrative decision-making and adjudication. ${ }^{186}$ Indeed, Kagan argues that the purpose of accountability mechanisms is 'not only to structure front-line decision making but also to provide mechanisms of accountability or review, hoping thereby to legitimate administrative decision making in the eyes of a variety of potential critics'. ${ }^{187}$

In that respect, there would seem to be a compelling case for rigorous judicial oversight of homelessness decision-making. The Upper Tribunal is fully independent from the executive, ${ }^{188}$ statutorily designated as a superior court of record ${ }^{189}$ and is headed by a Court of Appeal judge. ${ }^{190}$ It is therefore a court of considerable stature and it is contradictory for the appellate courts to reject the government's argument to conserve judicial resource, by making the Upper Tribunal immune from review, while admonishing county court judges hearing homelessness challenges to adopt a benevolent approach to the interpretation of internal review decisions and denying the applicability of Article 6. As already highlighted, homeless people are among the most vulnerable groups in society. Their health and wellbeing is poorer than that of the general population and they often experience the most significant health inequalities. ${ }^{191}$ Official statistics show that the mean age of death of homeless people is 32 years lower than the general population at 44 years, and even lower for homeless women, at just 42 years. ${ }^{192}$ Equally, decisions on immigration status potentially concern matters of life and death. ${ }^{193}$

\section{Conclusion}

Proportionate dispute resolution remains a core principle of the government's administrative justice agenda and encompasses issues of effectiveness and efficiency for both users and taxpayers. This

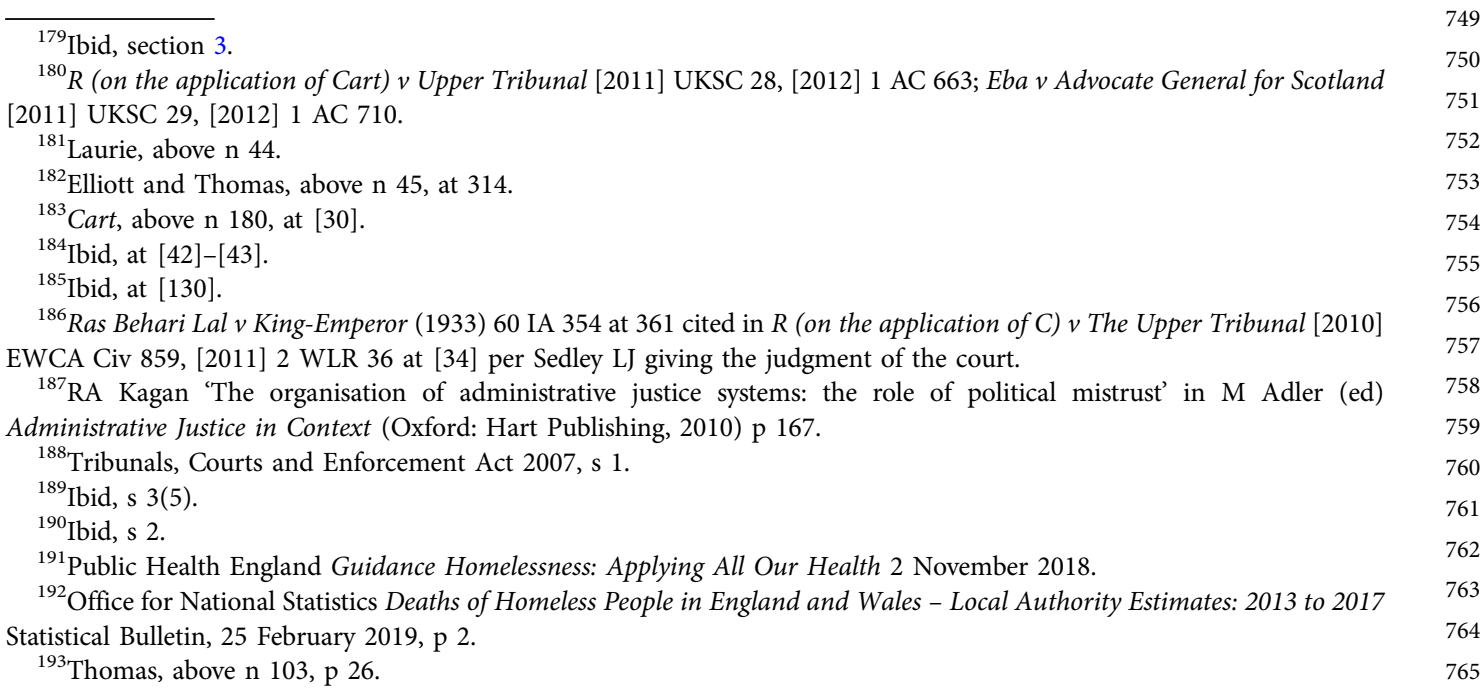


paper does not dispute Parliament's right to prescribe what it considers to be a proportionate review process, which includes an internal review as a mandatory precondition to accessing independent judicial review. Equally, it is true that, as Lord Hoffmann observed, it is not in the public interest that an excessive proportion of the social welfare budget is spent on administration and legal disputes. ${ }^{194}$ Nevertheless, it is also contrary to the public interest to dilute a statutorily prescribed process by instructing judges to give local authorities the benefit of the doubt, which potentially introduces an additional, informal layer of PDR and thereby risks denying appropriate judicial oversight. It is also misleading to characterise homelessness decision-making as a 'series of evaluative judgements' which significantly downplays the ambit of the law: in reality housing officers must master a sophisticated body of law and apply it lawfully to individual circumstances. That the eligibility criteria incorporate administrative discretion is undisputed but it is erroneous and potentially damaging to imply that it is a predominantly discretionary system which falls outside the procedural protection provided by Article 6 ECHR.

The government is fearful of 'judicial creep' into other administrative spheres, yet the ECtHR has signalled its approval of the current two-stage homelessness review process, and in doing so accepted the principle of PDR when accompanied by appropriate procedural safeguards. Given the vital importance of many areas of administrative decision-making, including homelessness, it is argued that the court (and the government) should focus on evaluating - and if necessary strengthening - the safeguards in place, rather than contesting the ambit of Article 6 on the basis of over-judicialisation.

${ }^{194} A$ Ali, above n 155 , at [5].

Cite this article: Laurie E (2020). Homelessness and the 'over-judicialisation' of welfare. Legal Studies 1-16. https://doi.org/ $10.1017 /$ lst.2020.22 